\title{
$\begin{array}{llllllllllllllllllllllll}P & R & Z & E & G & L & A & D & Z & A & C & H & O & D & N & I & O & P & O & M & O & R & S & K\end{array}$ ROCZNIK XXXIV (LXIII) ROK 2019 ZESZYT 2
}

\author{
PIOTR SIEMIŃSKI \\ ORCiD: 0000-0001-8359-1333 \\ Sąd Rejonowy Szczecin-Prawobrzeże i Zachód w Szczecinie \\ e-mail: piotr.sieminski89@gmail.com

\section{Profesora Alfreda Wielopolskiego (1905-1996) WKŁAD W ROZWÓJ PISARSTWA NAUKOWEGO}

Słowa kluczowe: Alfred Wielopolski, Pomorze Zachodnie, historia gospodarcza, archiwistyka

Keywords: Alfred Wielopolski, West Pomerania, economic history, archival studies

Alfred Wielopolski był jednym z twórców szczecińskiej nauki humanistycznej oraz ojcem założycielem środowiska historycznego'. Brał udział w tworzeniu się pierwszych instytucji naukowych w mieście. Ważnym przejawem jego pracy był wkład w pisarstwo naukowe. Tematyka pisanych artykułów i monografii była związana z naukowymi zainteresowaniami Profesora, które dotyczyły zagadnień historii gospodarczej oraz archiwistyki. Bardzo ważne były opracowania dotyczące tematyki pomorskiej - publikacje odnoszące się do politycznego i gospodarczego rozwoju Pomorza Zachodniego oraz historii wzajemnych relacji między tymi terenami a Polską na przestrzeni dziejów miały nie tylko charakter pionierski, ale stanowiły również ważny element integracji między tzw. Ziemiami Odzyskanymi a resztą kraju. Poniższy artykuł jest próbą przybliżenia najważniejszych z nich, ze wskazaniem okoliczności ich powstania, niejednokrotnie związanych z dramatycznymi wydarzeniami z życia Profesora.

1 T. Ślepowroński, Polska $i$ wschodnioniemiecka historiografia Pomorza Zachodniego (1945-1970). Instytucje - koncepcje - badania, Szczecin 2008, s. 293. 
Alfred Szczęsny Wielopolski urodził się 19 października 1905 roku w Chrobrzu i był trzecim z szóstki dzieci Aleksandra Erwina Wielopolskiego oraz Zofii Broel-Plater ${ }^{2}$. Początkowym wychowaniem Alfreda i Zygmunta Wielopolskich zajmował się guwerner Ernest Zaremba ${ }^{3}$. Po otrzymaniu podstawowego wykształcenia, w roku 1917 Alfred Wielopolski został wysłany do Warszawy, gdzie kontynuował naukę w gimnazjum św. Stanisława Kostki. Zdany egzamin maturalny umożliwił mu rozpoczęcie studiów prawniczych na Uniwersytecie Warszawskim, które ukończył w roku 1927. Następnie, w latach 1927-1928, przebywał w Montpellier we Francji, gdzie uczęszczał na zajęcia przygotowawczego studium medycznego. Studia te przerwał ${ }^{4}$ i powrócił do kraju, gdzie odbył służbę wojskową w Szkole Podchorążych Rezerwy we Włodzimierzu Wołyńskim oraz w 10. Dywizjonie Artylerii Konnej w Jarosławcu. Po zakończeniu służby wojskowej postanowił uzupełnić swe wykształcenie. W tym celu udał się do Szwajcarii, gdzie na Uniwersytecie w Fryburgu po trzech latach obronił pracę doktorską dotyczącą emigracji polskiej w Ameryce Południowej5.

Po uzyskaniu tytułu doktora nauk ekonomicznych i politycznych powrócił do Polski, gdzie wiosną 1931 roku podjął swoją pierwszą pracę. Na łamach tygodnika Stefana Krzywoszewskiego „Świat” opublikował swe pierwsze prace. Następnie, przez krótki czas, pracował w Instytucie Współpracy z Zagranicą,

2 Majątek ziemski wchodzący w skład Ordynacji Myszkowskiej znajdywał się w posiadaniu rodziny Wielopolskich od 1729 r., gdy zmarł ostatni przedstawiciel spokrewnionego rodu Myszkowskich. Wraz z posiadłościami otrzymali oni również tytuł margrabiowski, który przysługiwał dziedzicowi. Pozostałe dzieci tytułowały się tytułem hrabiowskim. W 1815 r. ordynację odziedziczył margrabia Aleksander Ignacy Wielopolski, należała do niego, mimo że w 1863 r., po wybuchu powstania styczniowego, udał się na emigrację (jako naczelnik rządu cywilnego Królestwa Polskiego starał się powstrzymać powstanie przez zorganizowanie tzw. branki). Majorat znalazł się następnie w posiadaniu jego syna, Zygmunta Andrzeja Wielopolskiego, działacza społecznego oraz polityka reprezentującego stronnictwo konserwatywne. Kolejnym dziedzicem był Aleksander Erwin Wielopolski, ojciec Alfreda Wielopolskiego. Ostatnim dziedzicem Ordynacji Myszkowskiej, po śmierci ojca w 1937 r., został najstarszy brat Alfreda, Zygmunt Konstanty.

3 Urodzony w 1890 r., zmarł 11 maja 1972 r. Po zakończeniu pracy w roli wychowawcy dzieci państwa Wielopolskich został sekretarzem ministra zdrowia Witolda Chodźki, następnie zaś pracował jako urzędnik w Ministerstwie Skarbu. W późniejszym okresie awansował na dyrektora Monopolu Spirytusowego oraz Tytoniowego. W trakcie wojny żołnierz Armii Polskiej na Środkowym Wschodzie, odznaczony Krzyżem Oficerskim Polonia Restituta i Złotym Krzyżem Zasług, później został doradcą Ministerstwa Skarbu Etiopii.

4 Jak wspomina sam Alfred Wielopolski, na skutek zaległości nagromadzonych w ciągu roku akademickiego oraz w obawie przed całkowitą kompromitacją nie przystąpił do egzaminów końcowych co ostatecznie oznaczało rezygnację z dalszych studiów.

5 A.W. Labuda, Kalendarium, w: A. Wielopolski, Z herbem po stużbach. Wspomnienia, Warszawa 2016, s. 519-522. 
a w końcu 1931 roku został zatrudniony na stanowisku referenta w Wydziale Społeczno-Prasowym w Kancelarii Cywilnej Prezydenta RP, pełniąc przy tym dodatkowo funkcję prywatnego sekretarza Adama Skwarczyńskiego, szefa Wydziału. Z racji niepełnosprawności A. Skwarczyńskiego wizytował urzędy gminne jako wysłannik rządowej komisji do usprawnienia administracji ${ }^{6}$.

W roku 1933, korzystając z nadarzającej się okazjī, Alfred Wielopolski przeniósł się do Wielunia, gdzie objął stanowisko wicestarosty. Funkcję tę pełnił do 1934 roku, kiedy to na osobistą prośbę prezydenta Mościckiego przejął kierownictwo w Referacie Społeczno-Prasowym w Kancelarii Cywilnej Prezydenta RP po śmierci A. Skwarczyńskiego ${ }^{8}$.

W 1937 roku rozpoczął pracę w Biurze Senatu RP, a w 1939 roku powołano go na stanowisko zastępcy dyrektora. Tuż przed wybuchem wojny został zmobilizowany do wojska, gdzie w stopniu podporucznika służył jako oficer zwiadu 3 baterii w 5 Dywizjonie Artylerii Konnej, która wchodziła w skład Krakowskiej Brygady Kawalerii w armii „Kraków”. Unikając niewoli, w okresie okupacji wraz z rodziną przeniósł się do majątku Stanisława Hofmokla, dziadka ze strony żony, Marii Salomei Wielopolskiej, i zajmował się folwarkiem Klemensówka. W okresie tym udzielał schronienia Żydom i innym osobom poszukiwanym przez nazistów. Ocalenie życia zawdzięczali mu m.in. prof. Józef Kostrzewski czy późniejszy prokurator Jerzy Sawicki ${ }^{9}$. Pod jego opieką znalazł się również Uniwersytet Podziemny. To dzięki tej działalności swój egzamin doktorancki z zakresu archeologii u prof. J. Kostrzewskiego mógł zdać Gerard Labuda ${ }^{10}$. W 1944 roku przeniósł się wraz z rodziną do Tuchowa, a następnie do Książa Wielkiego. Krótką, aczkolwiek znaczącą rolę odegrał w Radzie Głównej Opiekuńczej (dalej $\mathrm{RGO})^{11}$, swoje działania skupiając na opiece i pomocy dzieciom. Działalnością tą Alfred Wielopolski nie chwalił się i rzadko o niej wspominał, zwłaszcza że

6 Archiwum Państwowe w Szczecinie (dalej AP Szczecin). Zbiór nagrań. Wywiad z prof. Alfredem Wielopolskim, sygn. 9, Szczecin 1980.

7 Dotychczasowy zastępca starosty w Wieluniu, Stanisław Tarnowski, został awansowany na wicestarostę w Kaliszu. Tym samym na stanowisku zastępcy był wakat, który objął Alfred Wielopolski.

8 A. Wielopolski, Z herbem po stużbach..., s. 380.

9 A. Wielopolski, List do Obywatela Prezydenta Rzeczypospolitej, datowany: Szczecin, 23 września 1951 r., w: Listy do pierwszych sekretarzy KC PZPR (1944-1970), wybór i opracowanie J. Stępień, Warszawa 1994, s. 94-101.

${ }^{10}$ J. Kostrzewski, Z mego życia, Wrocław 1970, s. 230-235.

${ }^{11}$ B. Kroll, Rada Główna Opiekuńcza, Warszawa 1985, s. 415. 
w latach powojennych niejednokrotnie zarzucano mu kolaborację z nazistami ${ }^{12}$; m.in. na łamach czasopisma „Kulisy Ekspresu Wieczornego” ukazał się artykuł, który fałszywie zaliczał go do grona pracowników Biura Studiów RGO, którzy odpowiedzialni byli za przygotowywanie materiałów do rozmów prowadzonych między prezesem Rady Adamem Ronikierem a przedstawicielami Generalnego Gubernatorstwa $^{13}$.

\section{Początkowa działalność po wojnie}

Po zakończeniu wojny przez krótki czas zajmował stanowisko asystenta-wolontariusza w Katedrze Ekonomii Rolnej na Uniwersytecie Jagiellońskim. Po nawiązaniu kontaktu z Józefem Borowikiem, dyrektorem reaktywowanego Instytutu Bałtyckiego, przeprowadził się we wrześniu 1945 roku do Gdańska-Oliwy, w celu podjęcia pracy w charakterze sekretarza w tym Instytucie. Praca ta pozwoliła mu na rozwinięcie naukowych zainteresowań, które skupiały się wokół tematyki szeroko rozumianego Pomorza oraz kwestii gospodarczo-ekonomicznych pomorskich miast ${ }^{14}$. Pierwszymi pracami, które wyszły spod pióra A. Wielopolskiego po zakończeniu II wojny światowej, były dwie broszury wydane przez Instytut Bałtycki - Bydgoszcz. Nowe zadania i widoki rozwoju ${ }^{15}$ oraz Elblag: dzieje i przyszłośćc $c^{16}$.

${ }^{12}$ Rozmowa o Alfredzie Wielopolskim z prof. Józefem Stanielewiczem, przeprowadzona 21.11.2017 r.

${ }^{13}$ AP Szczecin. Spuścizna Alfreda Wielopolskiego, sygn. 94, k. 1-11.

${ }^{14}$ AP Szczecin. Zbiór nagrań. Wywiad z prof. Alfredem Wielopolskim, sygn. 9, Szczecin 1980.

${ }^{15}$ Obok rysu historycznego autor przedstawia swoje uwagi dotyczące rozwoju miasta jako punktu kluczowego dla transportu wewnętrznego między częścią wschodnią i zachodnią Polski. A. Wielopolski upatrywał owe „zadania” w czterech celach: 1) dzięki zmianom granic po wojnie Polska kontrolowała w całości bieg rzek Warty oraz Noteci, dodatkowo w jej granicach znalazła się również Odra. W celu zapewnienia rozwoju infrastruktury Bydgoszcz powinna stanowić swoisty węzeł, łączący transport kolejowy oraz wodny, umożliwiając m.in. dostawy węgla na teren całego Pomorza; 2) Bydgoszcz powinna przejąć na siebie większy ciężar handlu zagranicznego, odciążając w ten sposób część portów bałtyckich; 3) w następstwie tego przesunięcia miasto powinno odgrywać większą rolę zarówno dla przyszłego importu, jak i eksportu; 4) rozszerzenie zasięgu przemysłowo-handlowego miasta na wielkie połacie rolne, umiejscowione wzdłuż arterii Warty i Noteci. Zob. A. Wielopolski, Bydgoszcz. Nowe zadania i widoki rozwoju, Gdańsk 1945.

${ }^{16}$ Szczególnie zaakcentowany został okres pruskiego kryzysu, który w XIX w. doprowadził do stopniowego wyludniania się miasta i zanikania w nim przemysłu na rzecz rozwoju rolnictwa, a także aspekty dotyczące jego gospodarczego potencjału. W tym przypadku Wielopolski oddzielnie opisał wizje rozwoju Elbląga, odpowiednio biorąc pod uwagę samo miasto, jak i szerszą perspektywę całego kraju. Rozwój miasta, zdaniem autora, powinien skupić się, mimo braku 
Wymienione prace, biorąc pod uwagę datę ich wydania oraz podjętą tematykę, miały charakter pionierski. Zagadnienia Pomorza oraz tzw. Ziem Odzyskanych w dużej części kształtowały się dzięki pracownikom Instytutu Bałtyckiego, którzy mieli bogate doświadczenie sięgające okresu sprzed wybuchu wojny. Dzięki wiedzy ekonomicznej, znajomości języków obcych, w tym języka niemieckiego, oraz doświadczeniu nabytym podczas pracy w państwowym aparacie administracyjno-urzędniczym, A. Wielopolski miał podstawy do przeprowadzenia takich prognoz. Dodatkowo jego zainteresowania naukowe skupiały się w tym okresie na historii gospodarczej, na co wpływ miał zapewne przyjazd do Gdańska.

Oprócz pisania artykułów Profesor uczestniczył w różnych spotkaniach metodycznych jako przedstawiciel Instytutu Bałtyckiego ${ }^{17}$.

\section{Droga do Szczecina}

Decyzja o przeniesieniu się wraz z rodziną do Szczecina była umotywowana chęcią podjęcia pracy w Akademii Handlowej, którą rozpoczął w roku akademickim 1947/48. Jednocześnie, z dniem 1 września 1947 roku, A. Wielopolski został mianowany delegatem Instytutu Bałtyckiego w Szczecinie. Przyjazd do

bezpośredniego dostępu do morza, na przemyśle stoczniowym, który pozwoliłby na budowanie jednostek zarówno na potrzeby transportu morskiego, jak i śródlądowego oraz rozwoju infrastruktury niezbędnej do obsługi portów. Rozwój przemysłu stoczniowego miałby jednocześnie wpływ na rozwój przemysłu żelaznego, który początkowo nastawiony byłby na budowę kotłów i silników statków, w dalszej kolejności produkcja powinna zostać przestawiona na budowę samochodów, maszyn rolniczych i samolotów. Duży nacisk powinien zostać położony na rozwój przemysłu rolniczego. Bazując na rodzimej produkcji, należy rozwijać przemysł mleczny, mięsny oraz olejarski, a dzięki importowi zagranicznemu dodatkowo przemysł tytoniowy, lniarski, browarniczy oraz cukierniczy. Ponadto, istotny dla miasta byłby rozwój przemysłu drzewnego, umożliwiający produkcję statków oraz opakowań w postaci skrzyń, niezbędnych do rozwoju transportu. W dalszej kolejności, Elbląg, biorąc pod uwagę rozwój całego państwa, powinien dążyć do uczestnictwa w handlu morskim, by móc w pewien sposób odciążyć ośrodek Gdańsk-Gdynia. Dodatkowo, zdaniem A. Wielopolskiego, Elbląg powinien odegrać kluczową rolę w życiu naukowo-kulturowym. W mieście powinny powstać szkoły, które kształciłyby techników w zakresie budowy statków, maszyn, budowli melioracyjno-wodnych itd. Ostatnim wyznaczonym zadaniem było kulturalne „odczyszczenie” terenów Warmii z wszelkich nalotów niemczyzny. Zob. A. Wielopolski, Elbląg: dzieje i przyszłość, Gdańsk 1946.

${ }^{17} \mathrm{Na}$ jednym $\mathrm{z}$ takich spotkań, które dotyczyło podjęcia prób skodyfikowania prawa morskiego, poznał prof. Józefa Górskiego, który piastował wówczas stanowisko rektora Akademii Handlowej w Poznaniu. Dzięki tej znajomości poznał prof. Leona Babińskiego, który zostanie w przyszłości rektorem pierwszej szczecińskiej uczelni wyższej, szczecińskiego oddziału Akademii Handlowej. Wśród osób tworzących struktury akademii był również Alfred Wielopolski. Zob. AP Szczecin. Wywiad z prof. Alfredem Wielopolskim. Zbiór nagrań, sygn. 9, Szczecin 1980. 
miasta miał na celu również podjęcie próby utworzenia samodzielnego oddziału wspomnianego Instytutu. Zadanie to z przyczyn niezależnych od dyrekcji IB zakończyło się niepowodzeniem ${ }^{18}$. Prawdopodobnie było to spowodowane trudnościami wynikającymi z ograniczeń kadrowych, brakiem odpowiedniego zaplecza naukowego i lokalowego ${ }^{19}$. Ostatecznie jego stosunek pracy względem Instytutu uległ rozwiązaniu w 1948 roku $^{20}$.

$\mathrm{Na}$ wniosek prof. J. Górskiego w przydziale zajęć otrzymał prowadzenie wykładów z historii gospodarki oraz prawa skarbowego ${ }^{21}$. Ogółem w roku akademickim 1947/1948 podczas trzech trymestrów Wielopolski prowadził dwie godziny wykładów tygodniowo z zakresu historii gospodarczej na pierwszym roku studiów oraz kolejne dwie godziny tygodniowo ze skarbowości i prawa skarbowego na roku drugim. Dodatkowo jako kierownik prowadził seminarium skarbowe wraz z asystentem, Władysławem Stachowiakiem, oraz pełnił funkcję kuratora w Bibliotece Akademii Handlowej22.

Od 1 stycznia 1950 roku Akademia Handlowa została przekształcona w Wyższą Szkołę Ekonomiczną (dalej WSE). Alfred Wielopolski kontynuował wykłady z Historii Gospodarczej i Prawa Skarbowego do 31 sierpnia 1950 roku $^{23}$. W następnym roku akademickim do sekretariatu WSE wpłynęło pismo z Ministerstwa Szkół Wyższych i Oświaty, podpisane przez Dyrektora Lisonka. W datowanym na 15 marca lakonicznym zawiadomieniu ministerstwo nie wyraziło zgody na dalsze zatrudnienie dr. Wielopolskiego w jakimkolwiek charakterze. W odpowiedzi na zaistniałą sytuację A. Wielopolski skierował do rektora Leona

18 J. Stanielewicz, Alfred Wielopolski, w: Uniwersytet Szczeciński-prekursorzy, założyciele, ludzie nauki, red. J. Stanielewicz, W. Stępiński, E. Włodarczyk, Szczecin 2015, s. 426.

19 T. Ślepowroński, Powstanie i przemiany środowiska historycznego Szczecina do połowy lat pięćdziesiątych XX, w: W poszukiwaniu tożsamości. Październik 1956 na Pomorzu Zachodnim, red. A. Machałek, A. Makowski, Szczecin 2007, s. 152.

${ }^{20}$ AP Szczecin. Spuścizna Alfreda Wielopolskiego, sygn. 45, k. 16.

${ }^{21}$ Kadrę naukową w Akademii Handlowej w Szczecinie tworzyli ponadto m.in. wojewoda szczeciński Leonard Borkowicz, kierownik szczecińskiej i olsztyńskiej Delegatury Komisji Specjalnej do Walki z Nadużyciami i Szkodnictwem Gospodarczym - mgr Andrzej Burda, poseł na Sejm - Henryk Dąbrowicz oraz prezydent Szczecina - mgr inż. Piotr Zaremba. Więcej na temat rozwoju szkolnictwa akademickiego oraz ośrodków naukowych w Szczecinie pisali m.in. H. Lesiński, Uczelnie wyższe i nauka, w: Dzieje Szczecina, t. IV: 1945-1990, red. T. Białecki, Z. Silski, Szczecin 1998; H. Lesiński, W. Fenrych, Szkoły wyższe i rozwój życia naukowego, w: Pomorze Zachodnie 1945-1965, red. E. Dobrzycki, H. Lesiński, Z. Łaski, Poznań-Szczecin 1967. Zob. AP Szczecin. Spuścizna Alfreda Wielopolskiego, sygn. 46, k. 19.

${ }^{22}$ AP Szczecin. Spuścizna Alfreda Wielopolskiego, sygn. 46, k. 9-20.

${ }^{23}$ AP Szczecin. Spuścizna Alfreda Wielopolskiego, sygn. 48, k. 1-2. 
Babińskiego ${ }^{24}$ pismo, w którym zwrócił się z prośbą o wyjednanie przez profesora w Ministerstwie Szkolnictwa Wyższego i Nauki możliwości dokończenia bieżących zajęć (wykładów i egzaminów końcowych) do końca roku akademickiego. Prośbę swą motywował, w pierwszej kolejności, troską o wypełnienie założeń i zadań, jakie przyjęła Wyższa Szkoła Handlowa w drugim roku planu sześcioletniego ${ }^{25}$. Na miejsce zwalnianego doktora nie wyznaczono żadnego zastępstwa, dlatego Alfred Wielopolski ostrzegał przed ryzykiem niezrealizowania założeń programowych przyjętych dla trzech roczników studentów z zakresu wykładanych przez siebie przedmiotów. Wskutek przeprowadzonej 4 kwietnia narady u dyrektora Departamentu Kadr Ministerstwa Leon Babiński uzyskał upoważnienie do kontynuacji pracy przez Wielopolskiego do końca roku akademickiego w zakresie prowadzonych zajęć, seminariów oraz egzaminów ${ }^{26}$.

Przyczyny relegowania z uczelni nigdy oficjalnie nie podano, bez wątpienia składało się na nią w pierwszej kolejności nazwisko. W dalszej kolejności również przedwojenne doświadczenie i praca na rzecz państwa polskiego przyczyniły się do podejrzliwej postawy wobec jego osoby. W końcu zaś dr Wielopolski nie reprezentował posłusznej postawy biernego podporządkowania się władzy, jego charakter i silna osobowość były postrzegane przez radykałów jako zagrożenie ${ }^{27}$.

\section{Wbrew przeciwnościom}

Relegowanie z uczelni, zważywszy na to, że miał na utrzymaniu rodzinę, było wielkim ciosem. Sytuację dodatkowo pogarszał fakt, że poszukiwanie nowej pracy zakończyło się fiaskiem. Profesor miał nadzieję na zatrudnienie w Wojewódzkim Archiwum Państwowym (dalej WAP), jednak Naczelna Dyrekcja Archiwów Państwowych w Warszawie nie udzieliła żadnej odpowiedzi na złożone w lipcu podanie o przyjęcie do pracy. Dopiero po bezprecedensowym liście skierowanym

\footnotetext{
${ }^{24}$ Leon Babiński urodził się w 1891 r., zmarł w 1973 r. w Szczecinie. Z wykształcenia prawnik cywilista. W okresie międzywojennym uczestniczył w organizowaniu polskiego sądownictwa. Po wojnie związany ze szczecińskim oddziałem Akademii Handlowej, początkowo jako zastępca, a następnie rektor uczelni. Współzałożyciel Szczecińskiego Towarzystwa Naukowego oraz jego prezes w latach 1956-1970.

${ }^{25}$ AP Szczecin. Spuścizna Alfreda Wielopolskiego, sygn. 48, k. 6-7.

${ }^{26}$ Tamże, k. 5.

${ }^{27}$ W. Górski, Ocena działalności naukowej i społecznej Profesora Alfreda Wielopolskiego, Archiwum Uniwersytetu Szczecińskiego, Dział Nauki. Nadanie tytułu doktora Honoris Causa prof. Alfredowi Wielopolskiemu, sygn. 263/8, k. 11-15.
} 
do prezydenta Bolesława Bieruta sprawie nadano bieg ${ }^{28}$. Sam list niełatwo dziś jednoznacznie zinterpretować. Czytając go bezkrytycznie, można odnieść wrażenie, że autor całkowicie odżegnuje się od swojej przeszłości oraz klasy społecznej, z której pochodzi, nazywając jej członków „burżujami”. Styl wypowiedzi jest bowiem zbliżony do konwencji samokrytycznej ,nowomowy” partyjnej. Bardziej prawdopodobna jest jednak hipoteza, że stosowanie tak wyraźnych hiperbol w laudacji nowego systemu politycznego miało na celu w zakamuflowanie ironii. Ostatecznie, w styczniu 1952 roku dzięki interwencji Wydziału Propagandy KW PZPR w Szczecinie dr Wielopolski znalazł zatrudnienie w WAP w Szczecinie ${ }^{29}$.

Paradoksalnie, te ciężkie doświadczenia utraty pracy i problemy ze znalezieniem nowego źródła utrzymania miały jeden pozytywny aspekt. Zatrudnienie w WAP przypadło na bardzo burzliwy okres. W strukturze państwowej sieci archiwalnej było to archiwum nowe, o zasobie w dużej części stanowiącym materiał niemieckojęzyczny. Zbiory te stanowiły niezwykle cenne materiały dla naukowych zainteresowań Wielopolskiego, dotyczące dziejów zarówno Szczecina, jak i całego Pomorza Zachodniego, a dzięki pracy w archiwum miał do nich nieograniczony dostęp.

Dla samego WAP fakt zatrudnienia osoby ze znajomością języków obcych, zwłaszcza niemieckiego i francuskiego, z doświadczeniem pracy w administracji państwowej i z wykształceniem prawniczym oraz ekonomicznym, było zrządzeniem niemalże opatrznościowym. Jak sama określiła to nowa dyrektor WAP, Irena Okoń ${ }^{30}$, Alfred Wielopolski stanowił „cenną siłę naukową dla naszego Archiwum"31.

W tamtym czasie kadrę archiwum stanowiło grono młodych humanistów, dla których możliwość współpracy z Alfredem Wielopolskim pozwoliła na rozbudzenie w sobie naukowych aspiracji i zamiłowania do prac badawczych. W krótkim czasie nowe archiwum w Szczecinie, za duchowym przywództwem A. Wielopolskiego, zaczęło przekształcać się ośrodek naukowo-badawczy. Pracujący w nim archiwiści, w ślad za swym ,przewodnikiem”, przestali prezentować

\footnotetext{
${ }^{28}$ A. Wielopolski, List do Obywatela Prezydenta..., s. 94-101.

${ }^{29}$ AP Szczecin. KW PZPR w Szczecinie, Wydział Propagandy, sygn. 3549, k. 7.

${ }^{30}$ Irena Okoń urodziła się w 1907 r. Studia filozoficzne w zakresie historii ukończyła na Uniwersytecie Warszawskim. Po wojnie pracowała w WAP, a w latach 1951-1955 pełniła obowiązki dyrektora archiwum w Szczecinie. Była członkiem Polskiego Towarzystwa Historycznego, oddział w Szczecinie, pełniąc obowiązki sekretarza.
}

${ }^{31}$ AP Szczecin. Spuścizna Alfreda Wielopolskiego, sygn. 50, k. 15. 
postawę bierną wobec znajdujących się w archiwum materiałów. Impuls dany przez Wielopolskiego sprawił, że zaczęła rozwijać się tu historyczna nauka humanistyczna ${ }^{32}$.

Praca w WAP umożliwiła powrót do pracy naukowej. Do najważniejszych publikacji z lat 1952-1954 należały: fragmenty pracy zbiorowej Przeszłość Pomorza Zachodniego przemawia ${ }^{33}$ z 1952 roku, Polsko-Pomorskie spory graniczne w latach 1536-1555 34 opublikowane w „Przeglądzie Zachodnim” nr 4-5 z 1954 roku, Zagadnienie sił wytwórczych i rozwój stosunków społecznych $w$ rolnictwie Pomorza Zachodniego w pierwszej połowie XIX wieku $u^{35}$ wydane w „Kwartalniku Historycznym” nr 4 z 1954 roku oraz Sukiennictwo na Pomorzu

${ }^{32}$ W. Górski, Ocena działalności naukowej..., sygn. 263/8, k. 11-15.

${ }^{33}$ K. Chojnacka, W. Lachnitt, I. Okoń, A. Wielopolski, Przeszłość Pomorza Zachodniego przemawia, Szczecin 1952.

${ }^{34}$ A. Wielopolski, Polsko-pomorskie spory graniczne w latach 1536-1555, „Przegląd Zachodni” 1954, nr 4-5. Pomimo zakreślonych w tytule cezur, związanych z dostępem do źródeł znajdujących się w zasobie WAP, autor przytacza zarys historii ziemi czaplineckiej oraz pozostałych terenów granicznych (między Księstwem Pomorskim a Koroną), począwszy od darowizny Barnima II dla zakony templariuszy, aż do zaistniałych sporów granicznych w latach 1536-1555 przy przeprowadzaniu lustracji przez komorników królewskich oraz książęcych. W dużej części spór w omawianych latach dotyczy zatargów między wielkimi rodami posiadającymi swe majątki na pograniczu zarówno po jednej, jak i drugiej stronie (starostwa Drahim, Wałcz i Ujście oraz domeny-ekonomii Szczecinek i innych posiadłości lennych po stronie pomorskiej). Autor w sposób niezwykle dokładny odtwarza granicę ówczesnego państwa polskiego z Księstwem Pomorskim oraz zachodzące na przestrzeni wieków jej zmiany, z dokładnym przytoczeniem nazw jezior i rzek, które często ją wyznaczały. Artykuł jednocześnie był zbiorem opublikowanych źródeł w formie załączników w języku łacińskim, niemieckim oraz polskim.

${ }^{35}$ A. Wielopolski, Zagadnienie sit wytwórczych i rozwój stosunków społecznych w rolnictwie Pomorza Zachodniego w pierwszej połowie XIX wieku, „Kwartalnik Historyczny” 1954, nr 4. Artykuł dotyczył procesu zmian zachodzących w strukturze wiejskiej oraz społecznej. Napisany zgodnie z założeniami materializmu dialektycznego, obok odniesień do prac naukowych Lenina i Stalina, zawierał również dokładne odniesienia do materiałów źródłowych. Punktem wyjścia było przedstawienie, w jaki sposób, głównie dotyczyło to reform Steina-Hardenberga, zmieniała się własność ziemi. Nieracjonalna polityka pruska doprowadziła do skupienia większości gruntów w majątkach junkierskich, co nasiliło wyzysk chłopów oraz przeprowadzanych rugów, efektem czego były masowe ucieczki chłopów do miast oraz za granice. Ich miejsce zajmowali często chłopi polscy. Obok przemian społecznych zarysowana w pracy została również kwestia przemian zachodzących w rolnictwie i hodowli zarówno od strony jakościowej, jak i technologicznej. Autor wskazuje szereg przyczyn, które składały się na niski poziom rolnictwa - głównie zbyt długo stosowana trójpolówka, słaby poziom technologiczny oraz inne relikty systemu feudalnego. W końcowym fragmencie Wielopolski zaznacza ciągłość konfliktu klasowego, aż do lat 30. XX w., kiedy do władzy doszli naziści (wg nich sytuację na wsi mógł „poprawić” zbliżający się konflikt zbrojny, w wyniku którego planowano rozwiązać tzw. głód ziemi). 
Zachodnim w XIX wieku ${ }^{36}$ opublikowane w XVII tomie „Roczników Dziejów Społecznych i Gospodarczych" z 1955 roku. Dodatkowo na zlecenie Polskiej Akademii Nauk Wielopolski rozpoczął pracę nad tematyką gospodarczego rozwoju Pomorza Zachodniego ${ }^{37}$. Powyższe publikacje wraz z wcześniejszymi opracowaniami z okresu pracy w Instytucie Bałtyckim stały się podstawą do nadania 27 kwietnia 1956 roku Wielopolskiemu tytułu naukowego docenta przez Centralną Komisję Kwalifikacyjną dla Pracowników Nauki ${ }^{38}$. Uzyskanie tytułu docenta umożliwiło Alfredowi Wielopolskiemu ponowne podjęcie pracy dydaktycznej na uczelni.

\section{Powrót do pracy dydaktycznej}

Z propozycją objęcia kierownictwa Zakładu Historii Gospodarczej przez Alfreda Wielopolskiego wystąpił Tadeusz Rosner ${ }^{39}$, rektor Politechniki Szczecińskiej w $1956 \mathrm{roku}^{40}$.

A. Wielopolski wyraził gotowość podjęcia pracy w wymiarze pełnego etatu na uczelni, przy jednoczesnym zachowaniu pełnego etatu w Wojewódzkim Archiwum Państwowym w Szczecinie. Politechnika poinformowała o takim stanowisko Ministerstwo Szkolnictwa Wyższego. W nadesłanej odpowiedzi z września 1956 roku dyrektor Zarządu Wyższych Szkół Technicznych Józef Szymański poinformował, że niemożliwe jest pełnienie obowiązków kierownika Katedry Ekonomii Politycznej Politechniki Szczecińskiej przy jednoczesnym zachowaniu pełnego etatu w obecnym zakładzie pracy, którym było WAP. Wobec zaistniałej sytuacji J. Szymański zaproponował dwa rozwiązania. Rektor politechniki miał

${ }^{36}$ A. Wielopolski, Sukiennictwo na Pomorzu Zachodnim w XIX wieku, „Roczniki Dziejów Społecznych i Gospodarczych” 1955, nr 17. Artykuł dotyczy problematyki zanikania sukiennictwa na Pomorzu Zachodnim, szczególnie widocznego po kongresie wiedeńskim, kiedy to na skutek prowadzonych wojen celnych zamknięty zostaje dla lokalnych wytwórców dotychczasowy rynek zbytu na terenach Królestwa Polskiego i Rosji. Wobec rywalizacji z bardziej rozwiniętą technologicznie oraz lepiej skomunikowaną produkcją sukienniczą zachodniej części Niemiec wytwórcy z terenów Pomorza Zachodniego musieli zawiesić i zakończyć działalność.

${ }^{37}$ AP Szczecin. Spuścizna Alfreda Wielopolskiego, sygn. 49, k. 12-13.

38 Tamże, k. 18.

${ }^{39}$ Tadeusz Rosner (1899-1972) po wojnie wykładał w Szkole Inżynieryjnej w Szczecinie, której był dziekanem w latach 1950-1953, następnie pracował jako wykładowca na Politechnice Szczecińskiej, w latach 1953-1958 pełnił funkcję rektora. Był również jednym z założycieli Szczecińskiego Towarzystwa Naukowego, jego zainteresowania badawcze skupiały się wokół technologii włókien sztucznych.

${ }^{40}$ AP Szczecin. Spuścizna Alfreda Wielopolskiego, sygn. 52, k. 1. 
zaproponować i nakłonić dr. Wielopolskiego do zdecydowania się na podjęcie pełnego zatrudnienia na politechnice oraz połowy etatu w WAP. W przeciwnym razie ministerstwo godziło się na powołanie Wielopolskiego do pracy dydaktycznej na uczelni jedynie w wymiarze połowy etatu ${ }^{41}$. Profesor wybrał pełen etat na uczelni.

Naczelny dyrektor Archiwów Państwowych Henryk Altman ${ }^{42}$ w porozumieniu z dyrektorem WAP w Szczecinie przychylili się do prośby dr. Wielopolskiego, jednak w odwrotnej proporcji. Wymiar dodatkowej pracy dydaktycznej na Politechnice Szczecińskiej, na który początkowo zgodził się naczelny dyrektor Archiwów Państwowych, wyniósł pół etatu. Wobec takiego stanowiska Archiwum Państwowego i Ministerstwa Szkolnictwa Wyższego rektor zaangażował dr. Wielopolskiego od 1 września na samodzielnego pracownika nauki przy Katedrze Ekonomii Politycznej na Wydziale Inżynieryjno-Ekonomicznym Transportu Drogowego Politechniki Szczecińskiej w wymiarze połowy etatu ${ }^{43}$.

Aleksander Wielopolski, mimo łączenia dwóch etatów, kontynuował pisanie prac naukowych. Do najwcześniejszych publikacji, do roku 1958, należą poświęcone rozwojowi gospodarczemu i archiwoznawstwu: Memoriat landrata z Bytowa o położeniu ludności polskiej w powiecie bytowskim ${ }^{44}$, Materiaty do ruchu chtopskiego na Pomorzu Zachodnim w dobie Wiosny Ludów ${ }^{45}$, Drogi rozwoju

${ }^{41}$ Tamże, k. 2.

42 Henryk Altman (1897-1974), naczelny dyrektor Archiwów Państwowych w latach $1952-1965$.

${ }^{43}$ AP Szczecin. Spuścizna Alfreda Wielopolskiego, sygn. 52, k. 3.

${ }^{44}$ Jest to artykuł połączony z edycją źródła. Autorem memoriału jest landrat bytowski Henryk Fryderyk von Puttkamer. Okolicznościami skłaniającymi go do opisania sytuacji robotników pochodzenia polskiego była rosnąca ilość kradzieży (wycinanie drzew i kłusownictwo) dokonywanych przez Polaków. W ocenie von Puttkamera, przedstawiciela klasy junkierskiej, „tutejszy Polak nie posiada w ogóle zalet, które są podstawą wszelkiego rozwoju gospodarczego". Co ciekawe, w swych ocenach zachowuje on pewne nieścisłości, z jednej strony zarzucając np. Polakom alkoholizm, a z drugiej wskazując na konieczność spożywania alkoholu jako czynnika niezbędnego do wzmożonego wysiłku fizycznego. Całkowita więc ocena przeprowadzona przez landrata jest w rzeczywistości zniekształcona i nacechowana poczuciem wyższości względem ludności polskiej. A. Wielopolski, Memoriał landrata z Bytowa o położeniu ludności polskiej w powiecie bytowskim, „Studia i Materiały do Dziejów Wielkopolski i Pomorza” 1958, nr 1 (4).

${ }^{45}$ Publikacja ta wymienia i opisuje materiały znajdujące się w zasobach WAP. Zamieszki chłopskie w okresie Wiosny Ludów były zagadnieniem niepodejmowanym dotychczas w literaturze przedmiotu. Przytoczone archiwalia dotyczyły zapisków policyjnych i państwowych Regencji Szczecińskiej oraz burmistrza Trzebiatowa. Ruchy chłopskie były wywołane z jednej strony powiększającą się dysproporcją między statusem majątkowym chłopów (rosnące zubożenie) oraz junkrów, a także coraz bardziej zauważalnym różnicowaniem się samej warstwy chłopskiej, 
gospodarczego wsi i miast zachodnio-pomorskich w latach 1850-191446, które zostały opublikowane w zeszytach „Studia i Materiały do Dziejów Wielopolski i Pomorza", oraz Źródła do dziejów Polski w Wojewódzkim Archiwum Państwowym w Szczecinie ${ }^{47}$, które ukazały się w „Archeionie” w 1957 roku ${ }^{48}$.

głównie na skutek komasacji gruntów w procesie tzw. separacji specjalnej, co doprowadziło do podziału dotychczasowych wspólnot gromadzkich. Wspomniany ruch chłopski w okolicach Trzebiatowa, który należał do terenów domeny państwowej, został ostatecznie stłumiony przez oddziały wojskowe. Zob. A. Wielopolski, Materiały do ruchu chłopskiego na Pomorzu Zachodnim w dobie Wiosny Ludów, „Studia i Materiały do Dziejów Wielkopolski i Pomorza” 1958, nr 1 (4).

${ }^{46}$ Praca ta opisuje przemiany społeczne i gospodarcze na terenie prowincji Pomorze (w jej skład w okresie pruskim wchodziły regencje szczecińska, koszalińska oraz strzałowska), które doprowadziły ostatecznie do utraty tych ziem na rzecz Polski. Podczas pracy nad artykułem Wielopolski wykorzystał dużą ilość materiałów archiwalnych (głównie materiałów administracji urzędu naczelnego prezydenta prowincji Pomorze i dokumentów regencji) i statystycznych (wydawnictwa pruskiego biura statystycznego), znajdujących się w zasobie WAP oraz nielicznych opracowaniach naukowych. Tym samym opracowanie zagadnienia związanego z rozwojem gospodarczym Pomorza Zachodniego, we wspomnianym okresie, było uzupełnieniem luki nie tylko w literaturze polskojęzycznej, ale również niemieckojęzycznej. W sposób dokładny autor przedstawia zarys zmian zachodzących w rolnictwie Pomorza Zachodniego, charakterystycznych wyłącznie dla tych terenów Niemiec. Przemiany wpływające na tzw. pruską drogę rozwoju kapitalizmu na wsi doprowadziły do skupienia wielkich majątków ziemskich w rękach nielicznych junkrów, zaś ich folwarki na długie lata zdystansowały gospodarstwa chłopskie. Nieznaczna poprawa nastąpiła wraz z rozwojem kolejnictwa wąskotorowego. Jednak na skutek zbyt wyraźnego podziału klasowego wielu chłopów uciekało na zachód Niemiec, do silnie rozwijających się miast. Miejsce wychodźców zajmowali przybysze z Węgier, Włoch, a z czasem również pochodzenia polskiego. Obok opisania stosunków ludnościowych oraz przemian w rolnictwie autor podkreśla również znaczenie rozwoju miast oraz szlaków komunikacyjnych. Te ostatnie miały znaczny wpływ na rynek wewnętrzny i zewnętrzny, skupiający się na kontaktach ze Stanami Zjednoczonymi, Anglią czy Azją. Zob. A. Wielopolski, Drogi rozwoju gospodarczego wsi i miast zachodnio-pomorskich w latach 1850-1914, „Studia i Materiały do Dziejów Wielkopolski i Pomorza” 1958, nr 1 (4).

${ }^{47}$ Artykuł stanowi jednocześnie przewodnik po zasobie WAP dotyczącym zbiorów materiałów archiwalnych odnoszących się do Polski, pochodzących z kancelarii lokalnych książąt, następnie z kancelarii szwedzkiego namiestnika w Szczecinie i Strzałkowie, dalej z kancelarii pruskiej komory wojny i domen, zaś ostatecznie, po przeprowadzonej reformie Steina i Hardenberga, pruskiej kancelarii pruskiej administracji terytorialnej. Przytaczane materiały są charakteryzowane i podane w następujących grupach tematycznych: stosunki dyplomatyczne, stosunki gospodarcze (kwestia pożyczki zaciągniętej przez Zygmunta Augusta oraz kwesta żeglugi warciańsko-odrzańskiej), kwestie graniczne (wszelkie spory i wzajemne skargi). W dalszej kolejności scharakteryzowane zostały materiały wytwarzane poza kancelariami książęcymi, które dotyczyły spraw polskich - np. archiwalia odnoszące się do emigracji powstańców listopadowych i styczniowych na tereny Pomorza Zachodniego. Na końcu artykułu zostały podane materiały kartograficzne oraz wykaz badaczy korzystających ze zbiorów WAP wraz z podaniem badanej przez nich problematyki. Zob. A. Wielopolski, Źródta do dziejów Polski w Wojewódzkim Archiwum Państwowym w Szczecinie, „Archeion” 1957, nr 27.

${ }^{48}$ AP Szczecin. Spuścizna Alfreda Wielopolskiego, sygn. 52, k. 7. 
Najważniejszą pracą, powstałą w tym okresie, była monografia Gospodarka Pomorza Zachodniego w latach 1800-1918, do której autor kilka lat gromadził i porządkował materiały. Owa książka napisana została na zlecenie Zakładu Historii Polskiej Akademii Nauk i opublikowana ze środków Wydziału Nauk Społecznych Szczecińskiego Towarzystwa Naukowego w 1959 roku. W pewnej mierze była syntezą wcześniejszych artykułów dotyczących tematyki historii rozwoju gospodarczego terenów Pomorza Zachodniego, jak np. wspomniane Drogi rozwoju gospodarczego wsi i miast oraz Przyczyny zamierania sukiennictwa na Pomorzu Zachodnim w XIX wieku. Choć w swej monografii oprócz materiału źródłowego Wielopolski korzystał z obszernej literatury niemieckojęzycznej z okresu sprzed 1939 roku, to jednak nie powielał obecnego w nich jednostronnego spojrzenia na kwestie rozwoju gospodarczego. Autor skupił się na kolejnym opisaniu czterech okresów charakterystycznych dla ,,pruskiej drogi rozwoju kapitalizmu"49.

Na podstawie wyżej wymienionych prac Centralna Komisja Kwalifikacyjna dla Pracowników Nauki 26 lutego 1959 roku podjęła uchwałę, na mocy której Alfredowi Wielopolskiemu przyznano tytuł profesora nadzwyczajnego ${ }^{50}$.

Z dniem 15 lipca 1961 roku Ministerstwo Szkolnictwa Wyższego powołało Alfreda Wielopolskiego na stanowiska kierownika Katedry Historii Gospodarczej na Wydziale Inżynieryjno-Ekonomicznym Transportu Drogowego Politechniki Szczecińskiej w Szczecinie ${ }^{51}$ oraz przydzielono mu etat profesora nadzwyczajnego na Politechnice Szczecińskiej ${ }^{52}$.

\footnotetext{
${ }^{49}$ Opracowanie dotyczyło okresu od 1800 do 1850 r.; przybliżone zostały kulisy przeprowadzonych reform pruskich, mających na celu likwidację systemu feudalnego. W przypadku Pomorza reformy przeprowadzane na skutek klęsk poniesionych w wojnach napoleońskich zachodziły w tempie o wiele wolniejszym niż w zachodniej części Prus. Związane to było z agrarnym charakterem owych terenów. Druga część obejmowała okres do światowego kryzysu rolnego w $1882 \mathrm{r}$. Wielopolski skupił się na przedstawieniu przemian, jakie zachodziły w obszarze gospodarstw rolnych oraz w gospodarstwach chłopskich, które wiązały się z utrzymaniem wielkich własności junkierskich kosztem zahamowania rozwoju przemysłowego, a w następstwie do stopniowego wyludniania się wsi. Trzecia część dotyczyła kolejnych kryzysów, co skutkowało zmianą renty agrarnej. Okres do 1914 r. charakteryzował się również coraz częstszym sprowadzaniem pracowników sezonowych pochodzenia polskiego. Ostatnia część dotyczy lat Wielkiej Wojny, do wybuchu, której przyczynił się rozwoju niemieckiego imperializmu. Zob. A. Wielopolski, Gospodarka Pomorza Zachodniego w latach 1800-1918, Szczecin 1959.
}

${ }^{50}$ AP Szczecin. Spuścizna Alfreda Wielopolskiego, sygn. 52, k. 8.

${ }^{51}$ Tamże, k. 10.

52 Tamże, k. 11. 
We września 1961 roku został zmuszony do rezygnacji z pracy w WAP na skutek zmian przepisów dotyczących podejmowania dodatkowych zajęć zarobkowych przez samodzielnych pracowników nauki zatrudnionych w uczelniach wyższych oraz w Polskiej Akademii Nauk ${ }^{53}$. Nadal jednak utrzymywał ożywiony i stały kontakt z jego pracownikami. Minister szkolnictwa wyższego powołał go do Rady Archiwalnej, którą to funkcję pełnił w latach 1961-1964 ${ }^{54}$.

W 1965 roku opublikowana została kolejna monografia Wielopolskiego, nosząca tytuł Ustrój polityczny Pomorza Zachodniego w XIX wiek $u^{55}$. Praca ta była zwieńczeniem wieloletnich badań oraz licznych kwerend archiwalnych, odpowiadała również specyficznym zainteresowaniom, związanym z aspektami prawnoadministracyjnymi. Była dokładną i pierwszą w języku polskim kompleksową analizą dotyczącą oceny ustrojowego ukształtowania Pomorza Zachodniego pod względem władz państwowych oraz samorządowych, administracyjnych, sądowych i szkolnych. Główna oś narracji położona została na zależności pomiędzy strukturą gospodarczą Pomorza a pruskim centralizmem państwowym i dążeniami politycznymi lokalnych struktur samorządowych ${ }^{56}$. Jej potencjalnymi odbiorcami mieli być archiwiści oraz inni badacze interesujący się zagadnieniami politycznymi i ustrojowymi Pomorza Zachodniego. Zdaniem Jana Wąsickiego praca ta w doskonały sposób ukazywała ustrojową odrębność Pomorza Zachodniego względem pozostałej części Prus. Dodatkowo autor przeprowadził w niej niezwykle dokładną analizę struktur społecznych i zmian, jakie w ich obrębie zachodziły na przestrzeni lat. Tak jak większość prac A. Wielopolskiego również ta miała charakter pionierski. Do stworzenia powyższej monografii autor posłużył się obszernym materiałem archiwalnym oraz publikacjami niemieckojęzycznymi. Stanowiła również doskonałe uzupełnienie wcześniejszej monografii, dotyczącej rozwoju gospodarczego Pomorza Zachodniego ${ }^{57}$. Zdaniem Gerarda Labudy, recenzenta z ramienia Instytutu Historii Polskiej Akademii Nauk, praca

53 Tamże, k. 16.

${ }^{54}$ AP Szczecin. Spuścizna Alfreda Wielopolskiego, sygn. 49, k. 25-27.

55 A. Wielopolski, Ustrój polityczny Pomorza Zachodniego w XIX wieku, Poznań 1965.

56 J. Kępiński, Pismo rektora Politechniki Szczecińskiej z dnia 27 marca 1967 roku do Ministra Oświaty i Szkolnictwa Wyższego w sprawie przyznania nagrody dla prof. A. Wielopolskiego, w: teczka osobowa Alfreda Wielopolskiego, Archiwum Zachodniopomorskiego Uniwersytetu Technologicznego, brak foliacji.

57 J. Wąsicki, Opinia w sprawie nadania tytułu profesora zwyczajnego, AP Szczecin. Spuścizna Alfreda Wielopolskiego, sygn. 12, k. 2. 
stanowiła „wysokie osiągnięcie badawcze i dziejopisarskie”. Pomimo upływu lat jest do dziś niezwykle cennym i aktualnym źródłem do poznania przemian ustrojowych charakterystycznych dla Pomorza Zachodniego. Publikacja uzupełniała lukę $\mathrm{w}$ historiografii regionalnej oraz dodatkowo stanowiła cenną pomoc dla wszystkich badaczy zajmujących się zagadnieniami Pomorza.

Uchwałą Rady Państwa z dnia 8 czerwca 1968 roku Alfredowi Wielopolskiemu został przyznany tytuł profesora zwyczajnego nauk humanistycznych, jednocześnie minister oświaty i szkolnictwa wyższego, Roman Misiewicz, powołał go na stanowiska profesora zwyczajnego przy Katedrze Historii Gospodarczej na Politechnice Szczecińskiej ${ }^{58}$.

Na mocy zarządzenia rektora Politechniki Szczecińskiej oraz zarządzenia ministra oświaty i szkolnictwa wyższego w Instytucie Nauk Ekonomicznych i Społecznych Politechniki Szczecińskiej 1 września 1970 roku został utworzony Zakład Historii Gospodarczej i Doktryn Ekonomicznych ${ }^{59}$. W dniu następnym rektor Kępiński mianował prof. Wielopolskiego kierownikiem nowo utworzonego zakładu ${ }^{60}$. Funkcję tę piastował aż do odejścia na emeryturę w 1976 roku $^{61}$.

Od początku pracy na Wydziale Inżynieryjno-Ekonomicznym Transportu Drogowego zainteresowania Profesora rozszerzyły się o tematykę związaną z rozwojem transportu na przestrzeni dziejów oraz uchwyceniem zależności pomiędzy rozwojem poziomu transportu a rozwojem gospodarczym. We wcześniejszych pracach dotyczących samych kwestii gospodarczych zagadnienia związane z transportem były obecne. Z czasem stały się jednak widoczną i odrębną dziedziną zainteresowań Alfreda Wielopolskiego. Do najważniejszych prac z zakresu rozwoju transportu należą monografia Rozwój komunikacji miejskiej w Szczecinie w latach $1945-1970^{62}$, opublikowana przez Instytut Zachodniopomorski, oraz artykuł pod tytułem Rozwój handlu i żeglugi bałtyckiej w XIX i na początku

${ }^{58}$ AP Szczecin. Spuścizna Alfreda Wielopolskiego, sygn. 52, k. 29.

59 Tamże, k. 35.

${ }^{60}$ Tamże, k. 36-37.

${ }^{61}$ Tamże, k. 50-51.

${ }^{62}$ Monografia dotycząca szczecińskiej komunikacji była pracą niezwykle ciekawą, ponieważ dotyczyła tematyki bieżącej. Był to „pionierski szlak”, jak się okazało, możliwe jest opisanie zagadnienia współczesnego w połączeniu z zarysem historycznym. Profesor po raz kolejny posłużył się materiałami wcześniej niewykorzystywanymi. Zob. A Wielopolski, Rozwój komunikacji miejskiej w Szczecinie w latach 1945-1970, Szczecin 1970. 
$X X$ wiek $u^{63}$, opublikowany na łamach drugiego zeszytu XXXV tomu „Zapisków Historycznych" ${ }^{64}$.

Zwieńczeniem pracy w charakterze wykładowcy na Wydziale Politechniki Szczecińskiej oraz największym opracowaniem monograficznym, które wyszło spod pióra Wielopolskiego, była książka Zarys gospodarczych dziejów transportu do roku 1939. Opracowanie to było pierwszym w literaturze polskiej oraz światowej, syntetycznym zarysowaniem dziejów światowego transportu, począwszy od epoki neolitycznej, aż do wybuchu II wojny światowej. Opisywane w monografii zagadnienia dotyczyły kwestii rozwoju transportu oraz wzajemnego oddziaływania na siebie transportu, a także rozwoju gospodarczego danego obszaru. Dokładnej analizie zostały poddane stosunki społeczne, zachodzące w nich zmiany związane z rozwojem transportu i zależności między nimi zachodzące ${ }^{65}$.

Praca była owocem niezwykle starannej i pogłębionej analizy dostępnych opracowań. Opiewająca na 396 pozycji bibliografia pozwoliła Alfredowi Wielopolskiemu na stworzenie doskonałej i ponadczasowej, syntetycznej monografii, która uzupełniła dotkliwy brak zarówno w historiografii polskiej, jak i światowej. Synteza ta była również swoistym zakończeniem pewnego etapu w życiu Profesora, związanego z dydaktyczną rolą na Wydziale Inżynieryjno-Ekonomicznym Transportu Politechniki Szczecińskiej, będąc podsumowaniem wieloletnich zajęć wykładowych z dziedziny historii gospodarki i jednocześnie pierwszym kompleksowym podręcznikiem akademickim do poznania historii transportu.

Przemysław Małek, jeden z recenzentów, zwrócił uwagę na niezwykły styl, w jakim książka została napisana. Dzięki zastosowaniu francuskiej szkoły narracji oraz dostępnego języka była zrozumiała nie tylko dla studentów czy historyków, ale i dla szerszego grona czytelników, którzy dzięki wciągającej lekturze

${ }^{63}$ A. Wielopolski, Rozwój handlu i żeglugi bałtyckiej w XIX i na początku XX wieku, „Zapiski Historyczne" 1970, nr 2 (35).

${ }^{64}$ AP Szczecin. Spuścizna Alfreda Wielopolskiego, sygn. 52, k. 39.

${ }^{65} \mathrm{Na}$ wstępie Alfred Wielopolski zaznaczył, że w tytule użył słowa „zarys”. Zabieg ten spowodowany był świadomością autora o obszerności podjętego zagadnienia, zważywszy na obejmujący go okres oraz przekrój wszystkich epok przy jednoczesnych ograniczeniach wydawniczych. Zwłaszcza w związku z tymi ostatnimi profesor musiał skupić uwagę na krajach centralnej Europy, Ameryki, jednak z wyraźnym zaznaczeniem Polski oraz Rosji. A. Wielopolski, Zarys gospodarczych dziejów transportu do roku 1939, Warszawa 1975. 
mogli poznać ogromną ilość faktów związanych z rozwojem transportu, niepublikowanych wcześniej w literaturze polskiej ${ }^{66}$.

W przeciwieństwie do pozostałych prac z zakresu zagadnień gospodarczych czy społeczno-politycznych monografia ta nie dotyczyła ściśle regionu Pomorza Zachodniego. Charakterystyczna jest również cezura górna syntezy, kończąca się na roku 1939. Jak przyznał sam Profesor w jednej z rozmów z J. Piskozubem, była to data kończąca pewien etap w jego życiu, związany z okresem młodości oraz służby państwowej. Było to życie, które bezpowrotnie zakończyło się wraz z klęską kampanii wrześniowej w 1939 roku. Znaczącym wyróżnieniem, stanowiącym zwieńczenie akademickiej i naukowej pracy na Politechnice Szczecińskiej, było przyznanie mu tytułu doktora honoris causa w roku 1975. W uzasadnieniu wniosku o nadanie tego honorowego i zaszczytnego tytułu rektor Zygmunt Zieliński ${ }^{67} \mathrm{w}$ pierwszej kolejności wymienił ogromny dorobek naukowy Profesora, obejmujący 7 samodzielnych publikacji książkowych, 4 publikacje zbiorowe, 41 artykułów naukowych, 3 skrypty, 21 publikowanych recenzji oraz sporą ilość publikacji o charakterze popularyzatorskim ${ }^{68}$. Szczególnie ważny wkład w życie naukowe, polityczne oraz społeczne regionu i Szczecina miały prace z zakresu historii gospodarczej oraz polityczno-ustrojowej Pomorza. Prace prof. Wielopolskiego nie tylko miały charakter pionierski, ale dzięki sięgnięciu do najstarszych źródeł archiwalnych ukazywały odwieczną przynależność Pomorza Zachodniego do Polski. W ten sposób prace te wpływały pozytywnie na zjawisko integracji tych terenów z pozostałą częścią kraju, dając jednocześnie odpór niemieckiemu rewizjonizmowi, który rozwijał się po II wojnie światowej ${ }^{69}$. W dalszej części uzasadnienia został położony nacisk na niezwykle szerokie spektrum jego zainteresowań. Rektor politechniki prof. Józef Kępiński zaznaczał jednocześnie, że zainteresowania te nie zamykały się jedynie na tematyce regionalnej. Zwłaszcza

${ }^{66}$ P. Małek, Recenzja Zarysu gospodarczych dziejów transportu do roku 1939 autorstwa Alfreda Wielopolskiego, w: teczka osobowa Alfreda Wielopolskiego, Archiwum Zachodniopomorskiego Uniwersytetu Technologicznego, Szczecin 1976, brak foliacji.

${ }^{67}$ Urodzony w 1929 r., zmarł w 2009. Polski ekonomista oraz statystyk. W latach 1975-1981 rektor Politechniki Szczecińskiej. Od 1982 r. przebywał na stażu na Uniwersytecie Stanowym w Tempie (Floryda). Po powrocie rozpoczął pracę na Uniwersytecie Mikołaja Kopernika. Zainteresowania naukowe oscylowały wokół badań nad metodą analizy sezonowej oraz procesach stochastycznych.

${ }^{68}$ J. Kępiński, Uzasadnienie wniosku o nadanie tytutu doktora honoris causa Politechniki Szczecińskiej dla prof. Alfreda Wielopolskiego, w: teczka osobowa Alfreda Wielopolskiego, Archiwum Zachodniopomorskiego Uniwersytetu Technologicznego, brak foliacji.

${ }^{69}$ Tamże. 
w zakresie gospodarczym zainteresowania Alfreda Wielopolskiego sięgały do problematyki światowej, czego wyrazem były liczne publikowane przez niego recenzje książek, dotyczące badań prowadzonych m.in. przez uczonych radzieckich, niemieckich, angielskich, francuskich oraz amerykańskich ${ }^{70}$. Spośród tych prac szczególnie dawało się zauważyć zainteresowania problematyką niemcoznawczą ${ }^{71}$ Podkreślony został również niezwykle wysoki poziom pracy dydaktycznej. W zakresie studiów stacjonarnych i niestacjonarnych w Szczecinie oraz punkcie konsultacyjnym w Koszalinie w wykładach Alfreda Wielopolskiego przez wszystkie lata pracy dydaktycznej uczestniczyło ponad 3 tys. studentów ekonomii. Wkład Profesora w kształtowanie się naukowych ośrodków badawczych w Szczecinie również był nie do przecenienia ${ }^{72}$.

Należy zaznaczyć, że prace wychodzące spod jego pióra były typowe dla okresu, w którym tworzył. Wykorzystane metody charakterystyczne były dla historiografii doby dialektyzmu naukowego. Był to zabieg konieczny, by dzieła jego mogły ukazywać się drukiem. Niezależnie od własnych przekonań i odczuć pozostał on wierny maksymie rodowej, która brzmiała: Frangos non flectat (Uginaj się, ale nie łam ${ }^{73}$ ). Tym samym, niczym jego przodek margrabia Aleksander Wielopolski, tworzył on w „duchu pracy organicznej”, przyczyniając się do rozwoju pomorskiego środowiska naukowego oraz pisarstwa naukowego dotyczącego tematyki Pomorza Zachodniego. Określenia tego użył Kazimierz Kozłowski w trakcie jednego z wywiadów, jakie przeprowadził z A. Wielopolskim Zbigniew

\footnotetext{
${ }^{70}$ Przykładowe recenzje: E.V. Spiridonova, Ekonomiceskaja politika i ekonomiceskije wzgliady Petera I, Moskwa 1952 („Roczniki Dziejów Społecznych i Gospodarczych” 1954, nr 16); E. Klein, Von der Reform zur Restauration. Finanzopolitik und Gesetzgebung des preuss. Staate-kanzlers K.A. von Hardeberg, Berlin 1965 („Roczniki Historyczne” 1975, nr 41); J. Clifford, Aspect of Economic Development 1760-1960, Londyn 1967 („Roczniki Dziejów Społecznych i Gospodarczych" 1971, nr 32); P. Merlin, Les transports parisiens. Tetude de gegraphie economique et sociale, Paryż 1967 („Roczniki Dziejów Społecznych i Gospodarczych” 1967, nr 30) oraz A.F. Weber, The Growth of Cities in the XIX Century, New York 1963 („,Roczniki Dziejów Społecznych i Gospodarczych" 1965, nr 27).

${ }^{71}$ J. Kępiński, Uzasadnienie wniosku o nadanie tytułu doktora honoris causa..., brak foliacji.

${ }^{72}$ Tamże.

${ }^{73}$ Arystokrata na slużbie - reportaż Małgorzaty Furgi i Anny Kolmer. W rozmowie wzięli udział: Agnes Delahaye, Zofia Nieszkowska-Kwiecień, Jan i Andrzej Wielopolscy oraz prof. Józef Stanielewicz. Reportaż wyemitowany w Radiu Szczecin w związku z opublikowaniem w 2016 r. przez Naczelną Dyrekcję Archiwów Państwowych wspomnień prof. Alfreda Wielopolskiego.
} 
Kosiorowski ${ }^{74}$. Więcej na temat prowadzenia badań historycznych w dobie PRL pisali m.in. Rafał Stobiecki ${ }^{75}$ oraz Tadeusz Rutkowski ${ }^{76}$.

Z dniem 1 października 1976 roku prof. Wielopolski przeszedł na emeryturę. Emerytura ta miała charakter symboliczny, gdyż przez kolejne lata, działalność profesora Wielopolskiego w życiu kulturalnym oraz naukowym Szczecina była znacząca.

\section{Podsumowanie}

Działalność naukowa Alfreda Wielopolskiego nie skupiała się jednak wyłącznie wokół pisarstwa naukowego. Był on jednym z twórców i członków większości szczecińskich instytucji i towarzystw naukowych. Należał m.in. do Szczecińskiego Oddziału Polskiego Towarzystwa Historycznego, Instytutu Zachodnio-Pomorskiego, Sekcji Historycznej Towarzystwa Wiedzy Powszechnej oraz Szczecińskiego Towarzystwa Naukowego.

Jak zauważał Gerard Labuda, Alfred Wielopolski był w grupie osób, którym przyszło odbudować państwo z wojennej zawieruchy. Dodatkowo, w momencie przeprowadzenia się do Szczecina, zadanie odbudowy zostało rozszerzone o potrzebę zagospodarowania oraz doprowadzenia do zintegrowania tych terenów względem reszty kraju. W ocenie profesora Labudy Alfred Wielopolski jak mało kto, dzięki swojemu wykształceniu oraz doświadczeniu z okresu przedwojennego, zwłaszcza z zakresu pracy administracji państwowej, był do tego zaszczytnego, ale również ciężkiego i odpowiedzialnego zadania kandydatem doskonałym ${ }^{77}$.

Andrzej Piskozub w swej ocenie dorobku naukowego Alfreda Wielopolskiego podkreślił, że powstanie w 1985 roku Uniwersytetu Szczecińskiego było możliwe tylko dzięki działalności nielicznej grupy naukowych pionierów, spośród których czołowe miejsce zajmował właśnie profesor Wielopolski. Jego działalność była szczególnie widoczna w powstawaniu i kształtowaniu się

\footnotetext{
${ }^{74}$ Z. Kosiorowski, Jak woda szukająca formy, w: Mój ocean prawdziwy. Zbiór reportaży, Szczecin 1985, s. 168-169.

${ }^{75}$ R. Stobiecki, Historiografia PRL. Ani dobra, ani madra, ani piękna ... ale skomplikowana, Warszawa 2007.

${ }^{76}$ T. Rutkowski, Władze PRL i historycy. Okres gomułkowski (1956-1970), „Biuletyn Instytutu Pamięci Narodowej” 2008, nr 3 (8) oraz Nauki historyczne w Polsce 1944-1970. Zagadnienia polityczne i organizacyjne, Warszawa 2007.

${ }^{77}$ G. Labuda, O naukowej i organizacyjnej działalności Profesora Alfreda Wielopolskiego w Szczecinie, Archiwum Uniwersytetu Szczecińskiego, Dział Nauki, Nadanie tytułu doktora Honoris Causa prof. Alfredowi Wielopolskiemu, sygn. 263/8, k. 21-25.
} 
nauki humanistycznej. Za ten niepowtarzalny, nieoceniony i pionierski wkład w powstanie i rozwój humanistyki w ośrodku szczecińskim 19 października 1995 roku, w dniu 90. urodzin Alfreda Wielopolskiego, Uniwersytet Szczeciński nadał mu tytuł doktora honoris causa ${ }^{78}$. Było to wspaniałe i całkowicie zasłużone zwieńczenie dorobku naukowego oraz społeczno-kulturalnego wkładu Profesora w rozwój miasta. W ten sposób część długu, jaki Szczecin zaciągnął u Alfreda Wielopolskiego, został spłacony ${ }^{79}$.

\section{Bibliografia}

\section{Źródla archiwalne}

Archiwum Państwowe w Szczecinie

KW PZPR w Szczecinie,Wydział Propagandy, sygn. 3549.

Spuścizna Alfreda Wielopolskiego, sygn. 12, 45, 46, 48, 49, 50, 52, 86, 87, 94.

Zbiór nagrań, sygn. 9.

Archiwum Uniwersytetu Szczecińskiego

Dział Nauki, Nadanie tytułu doktora Honoris Causa prof. Alfredowi Wielopolskiemu, sygn. NB-4111, 263/8.

Archiwum Zachodniopomorskiego Uniwersytetu Technologicznego

Teczka osobowa Alfreda Wielopolskiego.

\section{Źródla opublikowane}

Kostrzewski J., Z mego życia, Wrocław 1970.

Wielopolski A., List do Obywatela Prezydenta Rzeczypospolitej, w: Listy do pierwszych sekretarzy KC PZPR (1944-1970), wybór i opracowanie J. Stępień, Warszawa 1994.

Wielopolski A., Z herbem po stużbach. Wspomnienia, Warszawa 2016.

\section{Opracowania}

Chojnacka K., Lachnitt W., Okoń I., Wielopolski A., Przeszłość Pomorza Zachodniego przemawia, Szczecin 1952.

Kosiorowski Z., Jak woda szukająca formy, w: Mój ocean prawdziwy. Zbiór reportaży, Szczecin 1985.

\footnotetext{
${ }^{78}$ Archiwum Uniwersytetu Szczecińskiego, Dział Nauki, Nadanie tytułu doktora Honoris Causa prof. Alfredowi Wielopolskiemu, sygn. NB - 4111, k. 1.

${ }^{79}$ A. Piskozub, Ocena dorobku naukowego prof. zw. dr. hab. Alfreda Wielopolskiego w zwiazku z postepowaniem o tytut doktora Honoris Causa Uniwersytetu Szczecińskiego, Archiwum Uniwersytetu Szczecińskiego, Dział Nauki, Nadanie tytułu doktora Honoris Causa prof. Alfredowi Wielopolskiemu, sygn. 263/8, k. 16-19.
} 
Kroll B., Rada Główna Opiekuńcza, Warszawa 1985.

Labuda A.W., Kalendarium, w: A. Wielopolski, Z herbem po stużbach. Wspomnienia, Warszawa 2016.

Lesiński H., Fenrych W., Szkoły wyższe i rozwój życia naukowego, w: Pomorze Zachodnie 1945-1965, red. E. Dobrzycki, H. Lesiński, Z. Łaski, Poznań-Szczecin 1967.

Lesiński H., Uczelnie wyższe i nauka, w: Dzieje Szczecina, t. IV: 1945-1990, red. T. Białecki, Z. Silski, Szczecina 1998.

Rutkowski T., Nauki historyczne w Polsce 1944-1970. Zagadnienia polityczne i organizacyjne, Warszawa 2007.

Rutkowski T., Władze PRL i historycy. Okres gomułkowski (1956-1970), „Biuletyn Instytutu Pamięci Narodowej" 2008, nr 3 (8).

Stanielewiecz J., Alfred Wielopolski, w: Uniwersytet Szczeciński - prekursorzy, załozyciele, ludzie nauki, red. J. Stanielewicz, W. Stępiński, E. Włodarczyk, Szczecin 2015.

Stobiecki R., Historiografia PRL. Ani dobra, ani madra, ani piękna... ale skomplikowana, Warszawa 2007.

Ślepowroński T., Polska $i$ wschodnioniemiecka historiografia Pomorza Zachodniego (1945-1970). Instytucje - koncepcje - badania, Szczecin 2008.

Ślepowroński T., Powstanie i przemiany środowiska historycznego Szczecina do połowy lat pięćdziesiątych XX w., w: W poszukiwaniu tożsamości. Październik 1956 na Pomorzu Zachodnim, red. A. Machałek, A. Makowski, Szczecin 2007.

Wielopolski A., Bydgoszcz. Nowe zadania i widoki rozwoju, Gdańsk 1945.

Wielopolski A., Drogi rozwoju gospodarczego wsi i miast zachodnio-pomorskich w latach 1850-1914, „Studia i Materiały do Dziejów Wielkopolski i Pomorza” 1958, nr 1 (4).

Wielopolski A., Elblag: dzieje i przyszłość, Gdańsk 1946.

Wielopolski A., Gospodarka Pomorza Zachodniego w latach 1800-1918, Szczecin 1959.

Wielopolski A., Materiaty do ruchu chłopskiego na Pomorzu Zachodnim w dobie Wiosny Ludów, „Studia i Materiały do Dziejów Wielkopolski i Pomorza” 1958, nr 1 (4).

Wielopolski A., Memoriat landrata z Bytowa o położeniu ludności polskiej w powiecie bytowskim, „Studia i Materiały do Dziejów Wielkopolski i Pomorza” 1958, nr 1 (4).

Wielopolski A., Polsko-pomorskie spory graniczne w latach 1536-1555, „Przegląd Zachodni" 1954, nr 4-5.

Wielopolski A., Rozwój handlu i żeglugi bałtyckiej w XIX i na początku XX wieku, „Zapiski Historyczne" 1970, nr 2 (35).

Wielopolski A., Rozwój komunikacji miejskiej w Szczecinie w latach 1945-1970, Szczecin 1970 .

Wielopolski A., Sukiennictwo na Pomorzu Zachodnim w XIX wieku, „Roczniki Dziejów Społecznych i Gospodarczych" 1955, nr 17. 
Wielopolski A., Ustrój polityczny Pomorza Zachodniego w XIX wieku, Poznań 1965.

Wielopolski A., Zadania naukowe Instytutu Zachodnio-Pomorskiego, „Szczecin. Czasopismo Regionu Zachodnio-Pomorskiego" 1962, nr 3.

Wielopolski A., Zagadnienie sił wytwórczych i rozwój stosunków spolecznych w rolnictwie Pomorza Zachodniego w pierwszej połowie XIX wieku, „Kwartalnik Historyczny" 1954, nr 4.

Wielopolski A., Zarys gospodarczych dziejów transportu do roku 1939, Warszawa 1975.

Wielopolski A., Źródła do dziejów Polski w Wojewódzkim Archiwum Państwowym w Szczecinie, „Archeion” 1957, nr 27.

\begin{abstract}
AbstrakT
W artykule przedstawiono sylwetkę prof. Alfreda Wielopolskiego (1905-1996). Przed II wojną światową pracownik administracji państwowej, m.in. wicestarosta Wielunia (1932-1934), pracownik kancelarii cywilnej prezydenta Ignacego Mościckiego, następnie pracownik i ostatecznie dyrektor Biura Senatu. Po wojnie sekretarz naukowy reaktywowanego Instytutu Bałtyckiego. W roku 1948 ostatecznie przeprowadza się do Szczecina, gdzie podejmuje pracę wykładowcy w Akademii Handlowej w Szczecinie, Wyższej Szkole Ekonomicznej (do 1951 r.) oraz po przerwie związanej z represjami politycznymi w Zachodniopomorskim Uniwersytecie Technicznym (1956-1976). W okresie „wymuszonej przerwy” w pracy dydaktycznej zatrudnienie znajduje w Wojewódzkim Archiwum Państwowym w Szczecinie (1952-1962). Alfred Wielopolski był jednym z pionierów i założycieli tworzącego się w Szczecinie środowiska humanistycznego. Jego działalność i wkład w rozwój humanistyki to oprócz pracy dydaktycznej w charakterze nauczyciela akademickiego oraz członkostwa w instytucjach naukowych działających w Szczecinie także publikowanie artykułów i monografii naukowych. Tematyką jego badań była archiwistyka, historia gospodarcza oraz zagadnienia pomorskie.
\end{abstract}




\title{
Professor Alfred Wielopolski's Contribution to the Development of Academic Writing
}

\begin{abstract}
The article presents Professor Alfred Wielopolski (1905-1996). Before the Second World War he worked as a state administration clerk, inter alia as deputy starost(a) of Wielun (1932-1934), as a clerk in the civil office of President Ignacy Mościcki, as a worker and finally Director of the Senate Office. After the war he was a scientific secretary of the reactivated Baltic Institute. In 1948 he moved to Szczecin, where he took up a job of a lecturer at the Academy of Trade in Szczecin, since 1951 the Higher Economic School, and after a break - resulting from political repression - at the West-Pomeranian Technical University (1956-1976). During the 'forced break' he was employed in the Regional State Archives in Szczecin (1952-1962). Alfred Wielopolski was one of the pioneers and founders of the Szczecin humanist milieu. His activity and contribution to the development of the humanities can be seen, in addition to being an academic lecturer and a member in academic institutions functioning in Szczecin, in publishing scientific articles and monographs. He was interested in archival studies, economic history and Pomeranian questions.
\end{abstract}

